\title{
How Integrated are Real Estate Markets with the World Market? Evidence from Case-wise Bootstrap Analysis
}

\author{
Abdulnasser Hatemi-J \\ Department of Economics and Finance, UAE University, \\ P.O. Box 17555, Al Ain, UAE. \\ Tel: +71-3-7133213, Fax: +71-3-7624384 \\ E-mail: $\underline{\text { AHatemi@uaeu.ac.ae }}$
}

\section{Eduardo Roca}

\author{
Department of Accounting, Finance and Economics, Griffith University, \\ Nathan, Queensland, Australia 4111 \\ Tel: +61-7-38757583, Fax: +61-7-3875 3719 \\ Email: E.Roca@griffith.edu.au \\ (corresponding author) \\ Abdulrahman Al-Shayeb \\ Department of Economics and Finance, UAE University \\ P.O. Box 17555, Al Ain, UAE \\ E-mail: A.Alshayeb@uaeu.ac.ae
}

\begin{abstract}
We investigate the extent by which real estate markets are integrated with the world market. We apply a case-wise bootstrap analysis - a method that is robust to non-normality and increased volatility that characterises financial markets, especially during periods of distress. We also take into account the effect of the global financial crisis. Our investigation is conducted in relation to five most important and highly internationalised real estate markets, namely, the US, UK, Japan, Australia and the United Arab Emirates (UAE). We find that the first four markets are integrated with the world market - with Japan, the US, and the UK being the most integrated, but the last one is not. Our results also show that the US real estate market crisis affected the five markets differently. It made the UAE, Australia and the US real estate markets more integrated internationally but resulted in the Japanese market becoming less globally integrated. In the case of the UK, the crisis did not affect at all its level of integration with the world market.
\end{abstract}

JEL Classifications: F36, G15, C22

Keywords: Beta; Casewise Bootstrap; Real Estate, World stock market

We would like to thank three anonymous referees and the editor of this journal Stephen G. Hall for their comments that resulted in an improvement of this paper after several revisions. We also would like to thank Viyan Taha for her research assistance. However, the usual disclaimer applies. 


\section{Introduction}

The issue of integration of real estate markets with the world market is one that has both theoretical and practical significance. If real estate markets are found to be significantly integrated with the world market, then the relevant model to use in the pricing of real estate investments would be an international asset pricing model since world systematic risk should be priced. This also implies that there is international contagion risk - that is, international events can spill over into domestic real estate markets. These have very significant implications for investors and policymakers particularly so that real estate markets are very fundamentally important to the economies of countries. The recent global financial crisis is a glaring testimony to this important role of real estate markets. If investors misprice real estate investments, then this can have negative consequences on other sectors of the economy and can also spill over internationally

In this paper, we provide fresh robust evidence on the integration of real estate markets with the world market. Specifically, we examine the extent of integration of the real estate markets of the US, the UK, Japan, Australia and the UAE with the world. We apply an international capital asset pricing model (ICAPM) which we estimate through the use of a case-wise bootstrap analysis - a method that is robust to non-normality and increased volatility that characterizes the financial markets especially during periods of distress. We take into account the global financial crisis (GFC) in our analysis.

Over the last decade, real estate markets in different countries have experienced rapid globalisation and internationalisation primarily aided by the development of real estate securities instruments which have allowed investors worldwide to participate in these markets (Bardhan and Kroll, 2007; Hobbs, Chin and Topintz, 2007; Eicholtz, et. al., 2009) 
Thus, it may be expected that real estate markets will now be integrated with the world market. However, real estate is a commodity that is not physically tradeable internationally, and this can hinder the integration of real estate markets with the world market. But with the advent of securitisation of real estate markets, which has gathered significant pace over the last decade (Liow 2007; Liow and Webb, 2006; Bond et. al., 2003), this would have overcome the underlying limitation. Notwithstanding this, there is evidence that prices in one real estate market do not respond significantly to movement in the prices of other real estate markets (Bardhan et. al., 2007). Thus, it appears that a priori, there is no clarity as to whether or not real estate markets are integrated with the world market.

As mentioned, we also examine the impact of the GFC on the integration between national real estate markets. A priori, it is difficult to say whether as a reaction to the US market debacle, real estate markets would keep to themselves or would be more connected with the world. On one hand, one would expect that real estate markets would keep to themselves in order not to be contaminated with what was happening in the US. Investors would tend to focus on their own market rather than on overseas markets. On the other hand, real estate markets might be tempted to open up more to welcome overseas investors who are fleeing from other markets. Investors also might be on the look out in other markets for bargains. Hence, real estate markets would be more connected to the world.

At present, there are only a very few studies which have examined the issue of global integration of real estate markets. Liow (2007) investigated the applicability of the international capital asset pricing model (ICAPM) in relation to the securitised real estate markets of Australia, Japan, the UK and Europe. This study used the world stock market and world real estate market as proxies for the world market. It estimated conditional and time varying betas and found the average betas of the markets to be less than one. The results of 
the study showed that the world real estate market has a positive effect on the real estate markets of Asia-Pacific, Hong Kong, Singapore and Malaysia, and a negative effect on the real estate markets of Europe and the UK. It also concluded that the world real estate market, as compared to the world stock market, was a better proxy for the world market. Ling and Naranjo (2002) also studied securitised real estate markets while Goetzmann and Wachter (2001) examined direct real estate markets. The findings of their investigations also showed that real estate markets are significantly affected by the world market. Given the limited number of studies, there is therefore scope for further studies on this issue.

Our study differs with the few previous studies on the integration of real estate markets with the world market in several ways. Firstly, we make use of a different estimation methodology - case wise bootstrapping, that provides a number of advantages. As previously mentioned, this method performs better than the standard methods particularly when the data are nonnormal and heteroscedastic which is the case during the financial crisis. Secondly, we also utilise a more updated and longer data set for the countries covered in the study as compared to those used in previous investigations. Thirdly, we examine the impact of the US subprime crisis on the level of integration of the US, UK, Japanese, Australian and UAE real estate markets with the world market. The impact of the recent crisis in the US real estate market on the global market risk for real estate markets is certainly an essential issue for investors given the magnitude of the crisis and the worldwide impact it had made. To our knowledge, this is the first study to take into account the effect of the Global Financial Crisis (GFC) on the world beta of real estate markets. Previous studies such as the one by Liow (2007) only examined the impact of the Asian economic crisis.

Our findings show that all five markets are integrated with the world market - with the US and UK markets being the most internationally integrated real estate markets and UAE being 
the least. Our results also demonstrate that the US sub-prime crisis has different effect on the real estate markets. We find that the US real estate market crisis made the US and UAE real estate markets to be more integrated internationally but resulted in the Japanese market becoming less globally integrated. On the other hand, the crisis did not affect the extent of integration of the Australian and UK markets with the world market, whether it is with the world stock market or the world real estate market. These results imply that global market risk should be priced in real estate investments, and that international shocks such as the US sub-prime crisis have differential impact on different real estate markets.

The rest of the paper is organised in the following way. The next section discusses methodology while Section 3 presents the empirical findings. The summary and conclusions are provided in Section 4.

\section{Methodology}

\subsection{Model Specification and Estimation}

In this paper, we investigate the extent of integration of real estate markets with the world market. We then determine the effect of the US real estate market crisis on this integration. In order to achieve these objectives, we estimate the beta for each real estate market in the context of an international capital asset pricing model (ICAPM). We use beta as a proxy for the extent of integration of each real estate market with the world market.

The method that we apply to estimate the ICAPM is a case-wise bootstrap approach that is suggested by Hatemi-J and Hacker (2005). This method is shown by the authors via simulation experiments to perform accurately when the financial markets are under distress 
and the standard assumptions of normal distribution and constant variance are not satisfied by the data. Since the underlying data is not normally distributed and the volatility is timevarying the standard methods based on the asymptotic distributions are not reliable. Thus, using the case-wise bootstrap approach is necessary in order to obtain correct inference. ${ }^{1}$ Calculations are implemented by using a statistical software component that is produced by Hacker and Hatemi-J (2009), which is available online. We make use of the following regression for calculating the international beta in the presence of a potential break:

$$
R_{i t}=\alpha_{i 0}+\alpha_{i 1} D_{i t}+\beta_{i 0} R_{m t}+\beta_{i 1} D_{i t} R_{m t}+\varepsilon_{i t},
$$

The denotations are defined as the following:

$R_{i, t}$ is the return of the real estate market $i(i=1, \ldots, 5)$ at time $t . R_{m t}$ is the world market return. $D_{i t}$ is a dummy variable with value zero for the period before the crisis and one for the period after the crisis for each market. The stochastic error term $\varepsilon_{i t}$ does not have to follow a normal distribution process with constant variance because the case-wise bootstrap method is robust to the non-existence of these statistical assumptions. If the estimated coefficient $\beta_{\mathrm{i} 1}$ is statically significant it means that there is a shift in the world market risk for country $i$ due to the crisis.

We also define the following matrix denotation to describe the case-wise bootstrap method that is used to estimate and test the statistical significance of the coefficients $\alpha_{i 0}, \alpha_{i 1}, \beta_{i 0}$ and $\beta_{i l}$ in model (1):

$$
Y=B X+\varepsilon
$$

where

\footnotetext{
${ }^{1}$ The diagnostic test results for normality and conditional heteroscedasticity that are presented in Table 1 reveal that the data is not normally distributed and heteroscedasticity prevails.
} 


$$
\begin{aligned}
Y & =\left[\begin{array}{l}
R_{i 1} \\
R_{i 2} \\
\vdots \\
R_{i T}
\end{array}\right] \text { a }(T \times 1) \text { vector, } X=\left[\begin{array}{cccc}
1 & R_{m 1} & D_{1} & D_{1} R_{m 1} \\
1 & R_{m 2} & D_{2} & D_{2} R_{m 2} \\
\vdots & \vdots & \vdots & \vdots \\
1 & R_{m T} & D_{T} & D_{T} R_{m T}
\end{array}\right] \text { a }(T \times 4) \text { matrix, } \\
B & =\left[\begin{array}{llll}
\alpha_{i 0} & \alpha_{i 1} & \beta_{i 0} & \beta_{i 1}
\end{array}\right] \text { a }(4 \times 1) \text { vector, and } \varepsilon=\left[\begin{array}{l}
\varepsilon_{i 1} \\
\varepsilon_{i 2} \\
\vdots \\
\varepsilon_{i T}
\end{array}\right] \text { a }(T \times 1) \text { vector. }
\end{aligned}
$$

The parameter vector can be estimated by the ordinary least squares as the following:

$$
\hat{B}=\left(X^{\prime} X\right)^{-1} X^{\prime} Y
$$

The implementation of the casewise bootstrap method consists of the following phases:

1. Create bootstrap time series $Y^{*}$ and $X^{*}$ via resampling with replacement, that is generate:

$$
Y^{*}=\left\{Y_{1}^{*}, Y_{2}^{*}, \cdots, Y_{T}^{*}\right\}, \quad Y_{j}^{*} \in Y \forall j . \text { Where } j=1, \cdots, T \text {. Note that } T \text { is the size of the }
$$

bootstrap sample. Similarly

$$
X^{*}=\left\{X_{1}^{*}, X_{2}^{*}, \cdots, X_{T}^{*}\right\}, \quad X_{j}^{*} \in X \forall j . \text { Where } j=1, \cdots, T \text {. }
$$

2. Estimate the parameter vector $(\hat{B})$ via the bootstrap time series as the following:

$$
\hat{B}=\left(X^{*} X^{*}\right)^{-1} X^{*^{\prime}} Y^{*}
$$

3. Iterate phases one and two $N$ times, where $N=10000$ is used in this case.

4. Finally, we acquire the casewise bootstrap coefficient vector $\hat{B}^{*}$ by taking the median of bootstrapped estimators. We prefer using the median instead of the mean value since the median is robust to outliers.

This case-wise bootstrap approach is also utilized to implement tests of statistical significance of each parameter as an element in the matrix $\hat{B}^{*}$. That is, the p-value for each 
null hypothesis in the form of $H_{0}: r B=0$ is obtained by the bootstrap approach. Here $r$ is a $(1 \times 4)$ vector that classifies the restrictions implied by the null hypothesis. As an example, to test the null hypothesis $\beta_{i 1}=0$ then $r=\left[\begin{array}{llll}0 & 0 & 0 & 1\end{array}\right]$. So as to find the $\mathrm{p}$-value for this null hypothesis, we need to first rank the estimated for $\hat{B}^{*}$ as described previously. The bootstrap $\mathrm{p}$-value for this hypothesis is then calculated as the following. In case the median for $r B^{*}$ is a positive number, then the p-value is the percentage of elements in the bootstrap distribution for $r B^{*}$ that are negative plus those that are greater than twice the median. However, in case the median for $r B^{*}$ is less than zero, then the p-value is the percentage of elements in the bootstrap distribution for $r B^{*}$ that are positive plus the percentage of elements in $r B^{*}$ that are less than double the median. The cut-off point of two times the median of $r B^{*}$ yields $p$ values, which are comparable to those symmetric two-sided tests in a traditional hypothesis testing approach as stated by Hatemi-J and Hacker (2005).

\subsection{Measurement of Variables and Data}

\section{$\underline{\text { Real Estate Markets Covered in the Study }}$}

As already discussed, this paper investigates the integration of the US, UK, Japanese, Australian and UAE real estate markets with the world market. These five markets are very active and highly internationalised markets located in different regions across the globe. The first four countries have the largest and most developed securitised markets in the whole world (Liow, 2007; Schindler, 2011; Wilson and Zurbruegg, 2003; Steinert and Crowe; 2001). In terms of absolute value, the US has the largest securitised property market (known as Real Estate Investment Trusts or REITs), although, proportionately, the US securitised sector is smaller than some of the securitised property markets of Asia or Europe (Wilson and 
Zurbruegg, 2003). For instance, about 55\% of all institutional grade real estate recorded in the Australian Property Council's database is listed, compared with similar listings for the US of $18 \%$, the UK of $17 \%$ and Japan of $10 \%$, as pointed out by Steinert and Crowe (2001). On the other hand, the UAE market is considered to be the most stable, secure and transparent real estate market in the Middle East region (Jones Lang LaSalle, 2012). Thus, these five markets provide an excellent laboratory for the investigation of the issue of global integration of real estate markets.

\section{World Market Proxy}

The real estate literature is silent as to which proxy is more appropriate to represent the world market, although the Morgan Stanley Capital International (MSCI) world index has been commonly used in international stock (Fama and French, 1998) and international real estate pricing studies (Bond et al., 2003). Following Liow (2007), we use two proxies for the world market: the MSCI world stock price index and the world real estate index. Liow (2007) finds that the use of the conditional betas relative to the world real estate index is more favoured. As many real estate markets are still less integrated with the global stock market, international real estate investors may still find it more useful to employ a world real estate benchmark (instead of a world stock market benchmark) to assist in their global asset allocation decisions and performance measurement exercises. This is an important finding for the current debate about the relative importance of an appropriate global benchmark in international real estate security markets.

\section{Real Estate Market Data, Sample Period and Structural Break}


Real estate serves an important avenue for portfolio diversification for investors due to its stable growth in value over time and its low correlation with traditional assets such as stocks and bonds across countries. Another attraction of real estate is that it acts as a hedge against inflation as documented, for instance, by Hudson et. al., (2005), Yunus (2009) and Bond et. al., (2006) among others. However, physical real estate has the disadvantage of being "lumpy" and "relatively illiquid". The processing of transactions relating to investment in physical properties may drag on for six months to even one year (Bond and Hwang, 2004).

An alternative method for investing in real estate that overcomes these disadvantages of physical real estate is investing through real estate securities. As pointed out by Yunus (2009), since the advent of securitization in the early 1960s and especially over the last decade, REITs (real estate investment trusts), REOCs (real estate operating companies) and private indirect vehicles have emerged as viable alternatives to domestic commercial real estate ownership, allowing more investors to get involved with real estate. The increase in demand for these securities by institutional investors has encouraged countries worldwide to introduce REIT-like securities which thereby enhance the growth of the securitised real estate markets. According to the National Association of Real Estate Investment Trusts (NAREIT), the global market capitalization of publicly listed property securities has grown by $170 \%$ from approximately $\$ 350$ billion to $\$ 945$ billion over the 7 -year period covering January 2000 to March 2007. By 2010, the value of the real estate securities market has reached $\$ 1$ trillion.

In this paper, we therefore focus on the securitised (equities) segment of the real estate market. By doing so, we are able to use higher frequency data than what can be obtained from the direct real estate market. This is advantageous in the investigation of market comovements as these often occur in short time horizons. The data employed in this study 
consist of publicly traded real estate stock price indices, in US dollars, quoted on a weekly basis, from Datastream for the five real estate markets under study, namely the United States, United Kingdom, Japan, Australia and the UAE - over the period 2005 to 2010. “Datastream's Real Estate Index aims to represent securitized real estate markets. The Thomson Datastream database constitutes the universe from which the index is drawn. Companies included in the index represent around $75-80 \%$ of the total market capitalization. Suitability for inclusion in the index is determined by market value and availability of the data. There are no liquidity requirements as well as no adjustments for non-public holdings of shares or for cross-holdings. The index constituents are reviewed at a quarterly basis and reset to represent the new top group of stocks by market value" (Serrano and Hoesli, 2009).

The sample period is from 01/06/2004-08/20/2013 and based on weekly data. The period of the structural break is chosen to be at August 1, 2007 because this was when the US real estate problem developed into crisis (Kiff and Mills, 2008, and Frank and Hesse, 2009). The commencement of the crisis can actually be traced back to the middle of 2005 . It was at this point in time that delinquencies in repayments by home borrowers started to increase. This situation continued to worsen as house prices also fell and interest rates increased and by 2007, a credit crisis had occurred. (Federal Reserve Bank of San Francisco 2008). A number of lenders succumbed to this crisis. For example, New Financial Century Corporation, the second largest home lender in 2006, disappeared from the scene. The increasing defaults by borrowers and the substantial fall in house prices also negatively affected the value of financial and credit products which were based on home mortgages, such as mortgaged back securities and collateralised debt obligations (CDO). Rating agencies then downgraded the ratings of products such as mortgaged backed securities and collateralised debt obligations due to the uncertainty in their values. This propagated across different financial markets so that starting in June 2007, a liquidity crisis was in the making. During this month, the hedge 
fund Bear Stearns collapsed as a result of their investments in CDOs. The month after, the German Bank IKB was also badly and had to be rescued by the German government, and in August, the French bank BNP Paribas had to halt redemptions for three of their funds which were deemed to be illiquid as a result of their involvement in US sub-prime mortgages. By August 1, the crisis was in full swing - the real estate crisis has fully become a liquidity crisis.

Thus, the structural break is taking place at 01:08:2007 in the estimations. We use weekly real estate stock returns $(\mathrm{R})$ which are obtained by taking the logarithmic difference of the stock index $(\mathrm{P})$ times 100 - that is, $\mathrm{R}_{\mathrm{t}}=100 *\left(\log \mathrm{P}_{\mathrm{t}}-\log \mathrm{P}_{\mathrm{t}-1}\right)$.

\section{Empirical Results}

\subsection{Diagnostics}

The continuous return of each variable is tested for normality and ARCH effects. The results that are presented in Table 1 show that the null hypotheses of normality and no ARCH effects are strongly rejected for the entire sample. Consequently, since these desirable statistical assumptions are violated then the standard methods based on asymptotic distributions might not perform accurately in this case.

\section{[INSERT Table 1 HERE]}

The descriptive statistics are also calculated for the subsamples before and after the crisis. The results indicate that the return of each market is reduced for the period after the crisis compared to the period before the crisis and the volatility has also increased significantly in each market due to the crisis. The diagnostic tests show once again that the data is not 
normally distributed and ARCH effects exist especially for the period after the crisis. Hence, it is important to make use of the casewise bootstrap method that is robust to the violations of normality and the existence of the ARCH effects for drawing valid empirical inference.

\section{[INSERT Table 2 HERE]}

In order to make sure that the spurious regression problem does not prevail, we also have conducted tests for unit roots. The estimation results of these tests are presented in Table 2, which indicate that the null hypothesis of one unit root is rejected in each market and the returns are stationary variables.

\subsection{Estimation Results}

The results of the estimation of the parameters are shown in Tables 3 and 4 . The estimated value for beta of the real estate market in each country is presented in Table 3 with regards to the world stock market and in Table 4 in relation to the world real estate market. It can be seen in both tables that the beta for the US, UK, Japan and Australia is significant but not for the UAE, which means that, before the crisis, the real estate markets of the US, UK, Japan and Australia are integrated with the world market while the UAE market is not. Based on the magnitude of the beta, before the crisis, the most globally integrated markets are Japan, the US and the UK depending on which proxy is used for the world market. It is also shown in both tables that, the US, UK, Japanese and Australian markets move positively with the world market as indicated by their positive betas.

[INSERT Table 3 and Table 4 HERE]

Further, we also find that the real estate markets of the US, Japan and Australia are more sensitive to the world real estate market than to the world stock market as these markets 
registered higher betas with the former than the latter. It is, however, the opposite for the UK. This is therefore indicative of segmentation of the real estate market and the equity market which is in line with the findings of Liow (2007).

The crisis seems to have affected only the world systematic risk of the real estate markets of the US, Japan, Australia and the UAE, but not the UK. It can be seen in Table 3 that the UAE, Australian and US real estate markets beta increased and hence became more integrated with the world stock market after the real estate crisis with the UAE registering the largest increase. Japan, on the other hand, became less globally integrated as indicated by the decrease in its beta after the crisis. The extent of integration with the world stock market of the UK real estate markets did not significantly change after the crisis.

Finally, it is worth noting that the results shown in Tables 3 and 4 show that all intercepts for all regressions are not significant, except that of the UAE. As the model being estimated is based on the CAPM, this implies that there are no abnormal returns that accrue to real estate - that is, returns on real estate are simply significantly a compensation for market risk in relation to the US, UK, Japanese and Australian real estate markets. Abnormal returns, however, are present in the UAE market.

\section{Conclusions}

In this paper, we investigate the extent of integration with the world market of the real estate markets of the US, UK, Japan, Australia and the UAE, taking into account the effect of the Global Financial Crisis. As a proxy for the level of integration, we estimate the beta based on an international capital asset pricing model. We utilise a case-wise bootstrap method - an 
approach that performs better than standard methods especially for data that are generated during crisis with non-normality and increased time-varying volatility.

The estimated beta is statistically significant in all models for the US, UK, Japan and Australia but not for the UAE. Japan, the US and the UK are the most integrated globally, while the UAE is not integrated at all with the world market. The former markets are the biggest and most internationalized real estate markets in the whole world, while the latter, although considered the most internationalized, active and transparent market in the Middle East region, is still a developing market.

The results also show that the US real estate market crisis had different impacts on the extent of integration of real estate markets with the world market. The UAE, Australian and US real estate markets became more globally integrated while the Japanese market less integrated, although in the case of the US, it was only with the world equity market and not with the world real estate market. On the other hand, the real estate market of the UK was not significantly affected by the real estate crisis. The UAE was the market that was most impacted by the crisis. It was not integrated at all with the world market before the crisis but after the crisis it became integrated.

The large increase in integration of the UAE real estate market with the world market after the crisis could have been the result of investors becoming more attracted to the UAE as a results of the plunge in real estate prices in that country during the crisis. During the crisis, the UAE real estate market was one of the most badly hit, particularly the Dubai emirate which even necessitated a bail out. This market has been establishing a reputation of being an open, transparent and international market and hence, it could have led to this market 
becoming a beneficiary of worldwide investors looking for higher returns in the real estate market.

The increased integration of the US market with the world equity market after the real estate crisis would have been a consequence of the US real estate market becoming also a depressed industry with real estate prices plunging to very low levels. This attracted significant foreign investors looking for higher future returns in their portfolios which could have therefore increased the integration of the US real estate market with the world. Investors, however, would have gone into the real estate sector in the equity market, or the REIT, rather than into the physical market. In fact, with regards to the latter, there may have been a decreased in investments as the US real estate market became less integrated with the world real estate market.

As with the US, Australia also became more integrated with the world market after the US real estate crisis. The Australian real estate market was not as greatly affected as the US and the UAE and hence, prices did not really plunge as much as those in the two countries. However, the Australian market has established a reputation of being a stable and less risky market (Bardhan, et al, 2012) and hence, it could have been the beneficiary of investment money seeking refuge in more stable markets. The UK property market was also less affected by the real estate crisis and hence, did not suffer severe decreases in prices (Bardhan, et al, 2012), and hence, its linkages with the world market after the GFC were not affected significantly.

These results have important implications for investors and policymakers. These provide further confirmation that real estate markets, at least in the case of the major markets, are indeed integrated with the world market. Thus, international systematic risk plays a 
significant role in the pricing of real estate securities. This also implies that international contagion risk exists among real estate markets. Domestic real markets are therefore susceptible to shocks coming from foreign markets. If contagion risk is to be addressed, this requires the international cooperation among financial regulators.

\section{References}

Bardhan, A. and Kroll, C. (2007), Globalisation and the Real Estate Industry: Issues, Implications and Opportunities, paper prepared for the Sloan Industry Studies Annual Conference, Cambridge.

Bardhan, A., Edelstein, R. and Tsang, D. (2007). Global Financial Integration and Real Estate Security Returns, Electronic copy available at: http://ssrn.com/abstract=905313.

Bardhan, A., Edlestein, R.and Kroll, C. (2012). A Comparative Context for US Housing Policy: Housing Markets and the Financial Crisis in Europe, Asia and Beyond, Bipartisan Policy Center, USA.

Bond S.A. and Patel, K. (2003) The conditional distribution of real estate returns: are higher moments time varying, Journal of Real Estate Finance Economics, 26:319-339.

Bond SA and Hwang S (2004) Liquidity risk and real estate: a quantitative approach to assessing risk, paper presented to the 2004 European Real Estate Society annual meeting. Milan, June 2004

Bond, S.A., Dungey, M. and Fry, R. (2006). A Web of Shocks: Crises across Asian Real Estate Markets, Journal of Real Estate Financial Economics, 32, 253-274.

Dell'Ariccia, G., Igan, D. and Laeven, L. (2008), “Credit Booms and Lending Standards: Evidence from the Subprime Mortgage Market, (unpublished; Washington: International Monetary Fund).

Eichholtz, Piet M. A. and Kok, Nils, The EU REIT and the Internal Market for Real Estate (November 2007). Available at SSRN: http://ssrn.com/abstract $=1081198$ or http://dx.doi.org/10.2139/ssrn.1081198

Eicholtz, P., Gugler, N., and Kok, N. (2009). Transparency, Integration, and the Costs of International Real Estate Investment, Electronic copy available at:

http://ssrn.com/abstract=1346409. 
Fama, E. and French, K.R. (1998) Value versus growth: the international evidence, Journal of Federal Reserve Bank of San Francisco.

Frank, N. and Hesse, H. (2009) Financial Spillovers to Emerging Markets During the Global Financial Crisis, Working Paper WP/09/104, International Monetary Fund.

Goetzmann, W.N. and Wachter, S.M. (2001) The global real estate crash: evidence from an international database, in A Global Perspective in Real Estate Cycles (edited by S. J. Brown and C. H. Liu), Kluwer Academic Publishers, Boston, MA, pp. 5-23.

Goetzmann, W.N. (1993) The Single Family Home in the Investment Portfolio. Journal of Real Estate Finance and Economics, 6, 3, 201-22.

Hacker R.S. and Hatemi-J A. (2009) ContagT: GAUSS module to implement a pairwise bootstrap test for contagion, Boston College Department of Economics, Statistical Software Components, number G00007. Available online.

Hatemi-J, A. and Hacker, R. S. (2005) An Alternative Method to Test for Contagion with an Application to the Asian Financial Crisis, Applied Financial Economics Letters, 1(6), 343347.

Hobbs, P.; Chin, H. and Topintzi, E. (2007) "Global Real Estate Investment and Performance," London: RREEF Research

Hudson-Wilson, S.; Gordon J.N.; Fabozzi F.J., Anson, M. and Gilliberto, S.M. (2005) Why Real Estate? The Journal of Portfolio Management, 31, 5, 12-21.

Jones Lang LaSalle (2012). Global Real Estate Survey. Accessed through http://llenrock.com/blog/top-10-most-transparent-cre-markets-in-the-middle-east-africa/ on January 23, 2013.

Kaminsky, G.L. and Schmukler, S.L. (1999), "What triggers market jitters? A chronicle of the Asian crisis", Journal of International Money and Finance, 18, 537-60.

Kiff, J., and P. Mills, (2008) "Money for Nothing and Checks for Free: Recent Developments in U.S. Subprime Mortgage Markets," IMF Working Paper 07/188 (Washington: International Monetary Fund).

Ling, D.C. and Naranjo, A. (2002) Commercial real estate return performance: a crosscountry analysis, Journal of Real Estate Finance and Economics, 24(1/2), 119-142.

Liow, K.H. and Sim, M.C. (2006) The Risk and return profile of Asian Real estate stocks, Pacific Rim Property Research Journal, 12(3), 283-310.

Liow, K.H. and Webb, J. (2005) Common factors in international securitized real estate markets, Working Paper, Department of Real Estate (National University of Singapore) and Department of Finance, Cleveland State University. 
Liow, KH (2007), The Dynamics of Return Volatility and Systematic Risk in International Real Estate Security Markets, Journal of Property Research, 24, 1, 1-29.

Ng S. and Perron P. (2001) Lag Length Selection and the Construction of Unit Root Tests with Good Size and Power, Econometrica, 69(6), 1519-1554.

Perron, P. (1989) The Great Crash, the Oil Price Shock, and the Unit Root Hypothesis, Econometrica, 57(6), 1361-1401.

Schindler, F. (2011). "Market efficiency in the emerging securitized real estate markets", Journal of Real Estate Literature, 19, 111-150.

Steinert, M. and Crowe, S. (2001) Global Real Estate Investment Characteristics, Portfolio Allocation and Future Trends, Pacific Rim Property Research Journal, 2001, 7(4), 223-239.

Wilson, P. and Zurbruegg, R. (2003) International Diversification of Real Estate Assets? Is It Worth It? Evidence from the Literature, Journal of Real Estate Literature, 11, 3, 259277.

Yunus, N. (2009) Increasing Convergence between U.S. and International Securitised Property Markets: Evidence Based on Cointegration Tests, Real Estate Economics, 37, 3, 383-411. 
Table 1a. Descriptive statistics and diagnostic tests for the entire sample during 01-2004 to $08-2013$ on daily basis (502 observations).

\begin{tabular}{|c|c|c|c|c|c|c|c|}
\hline & Australia & Japan & UAE & UK & US & $\begin{array}{l}\text { World Real } \\
\text { Estate }\end{array}$ & $\begin{array}{l}\text { World } \\
\text { Stock } \\
\text { Market }\end{array}$ \\
\hline Mean & -0.000247 & 0.001448 & 0.002940 & -0.000199 & 0.000605 & 0.000758 & 0.000851 \\
\hline Median & 0.002223 & 0.004228 & 0.002006 & 0.002281 & 0.005128 & 0.003946 & 0.003346 \\
\hline Maximum & 0.208445 & 0.170730 & 0.240884 & 0.201028 & 0.120618 & 0.134803 & 0.117940 \\
\hline Minimum & -0.355854 & -0.223144 & -0.307579 & -0.265141 & -0.255146 & -0.158507 & -0.139774 \\
\hline Std. Dev. & 0.042584 & 0.043736 & 0.066628 & 0.044361 & 0.037290 & 0.030954 & 0.024544 \\
\hline Skewness & -1.284738 & -0.617500 & -0.317307 & -0.682213 & -1.303380 & -0.812757 & -0.744981 \\
\hline Kurtosis & 15.47816 & 6.811167 & 5.788418 & 8.983436 & 10.20017 & 7.419157 & 7.012632 \\
\hline Normality & $<0.00001$ & $<0.00001$ & $<0.00001$ & $<0.00001$ & $<0.00001$ & $<0.00001$ & $<0.00001$ \\
\hline $\mathrm{ARCH}$ & 0.06950 & $<0.00001$ & 0.19790 & $<0.00001$ & 0.00160 & $<0.00001$ & $<0.00001$ \\
\hline
\end{tabular}

Table 1b. Descriptive statistics and diagnostic tests for the pre-crisis period during 012004 to $07-2007$ on daily basis (187 observations).

\begin{tabular}{|c|c|c|c|c|c|c|c|}
\hline & Australia & Japan & UAE & UK & US & $\begin{array}{c}\text { World Real } \\
\text { Estate }\end{array}$ & $\begin{array}{c}\text { World } \\
\text { Stock } \\
\text { Market }\end{array}$ \\
\hline Mean & 0.002986 & 0.004613 & 0.011448 & 0.003737 & 0.002302 & 0.003222 & 0.001886 \\
\hline Median & 0.003351 & 0.004938 & 0.005385 & 0.006235 & 0.006580 & 0.005475 & 0.003176 \\
\hline Maximum & 0.068621 & 0.105892 & 0.240884 & 0.092742 & 0.052637 & 0.054717 & 0.044900 \\
\hline Minimum & -0.072564 & -0.143788 & -0.184279 & -0.061489 & -0.084340 & -0.066983 & -0.053327 \\
\hline Std. Dev. & 0.022171 & 0.038952 & 0.067538 & 0.025317 & 0.024344 & 0.018596 & 0.015240 \\
\hline Normality & 0.46157 & 0.00423 & 0.000013 & 0.505197 & $<0.00001$ & $<0.00001$ & 0.000066 \\
\hline $\mathrm{ARCH}$ & 0.71310 & 0.11980 & 0.47260 & 0.42610 & 0.17560 & 0.67740 & 0.11440 \\
\hline
\end{tabular}

Table 1c. Descriptive statistics and diagnostic tests for the after-crisis period 08-2007 to 082013 on daily basis (315 observations).

\begin{tabular}{|c|c|c|c|c|c|c|c|}
\hline & & & & & & World Real & $\begin{array}{c}\text { World } \\
\text { Stock } \\
\text { Market } \\
\text { Estate }\end{array}$ \\
\hline Mean & -0.002167 & -0.000432 & -0.002111 & -0.002536 & -0.000403 & -0.000705 & 0.000237 \\
\hline Median & 0.001168 & 0.002821 & 0.000755 & -0.000888 & 0.004460 & 0.002553 & 0.003687 \\
\hline Maximum & 0.208445 & 0.170730 & 0.224303 & 0.201028 & 0.120618 & 0.134803 & 0.117940 \\
\hline Minimum & -0.355854 & -0.223144 & -0.307579 & -0.265141 & -0.255146 & -0.158507 & -0.139774 \\
\hline Std. Dev. & 0.050914 & 0.046300 & 0.065669 & 0.052398 & 0.043185 & 0.036306 & 0.028681 \\
\hline Normality & $<0.00001$ & $<0.00001$ & $<0.00001$ & $<0.00001$ & $<0.00001$ & $<0.00001$ & $<0.00001$ \\
\hline ARCH & 0.06990 & 0.00010 & 0.3827 & $<0.00001$ & $<0.00001$ & $<0.00001$ & $<0.00001$ \\
\hline
\end{tabular}

Note: The normality assumption is tested by the Jarque-Bera test. The ARCH effects are tested by using the Engle's LM test. The p-values for these two tests are presented. 
Table 2. Unit root test results

\begin{tabular}{|c|c|}
\hline Variable & $\mathrm{H}_{0}: \mathrm{I}(1), \mathrm{H}_{1}: \mathrm{I}(0)$ \\
\hline Australia & 0.00011 \\
\hline Japan & 0.00192 \\
\hline UK & 0.00022 \\
\hline US & 0.00139 \\
\hline UAE & 0.00365 \\
\hline World Stock Market & 0.00061 \\
\hline World-Real Estate & 0.00042 \\
\hline
\end{tabular}

The null hypothesis of one unit root in each variable is tested by the $\mathrm{Ng}$ and Perron (2001) test. The p-value for each test is presented. We also tested the unit root hypothesis using the Perron (1989). The break period was the first of August 2007. The results show that the null hypothesis that the returns are integrated could be rejected in each case. 
Table 3. Results of case-wise resampling bootstrap method with beta based on the world stock market index

\begin{tabular}{|c|c|c|c|c|}
\hline \hline Country & Intercept $\left(\alpha_{0}\right)$ & Change in Intercept $\left(\alpha_{1}\right)$ & Slope $\left(\beta_{0}\right)$ & Change in Slope $\left(\beta_{1}\right)$ \\
\hline \multirow{2}{*}{ Australia } & 0.0018 & -0.0043 & 0.6465 & 0.5255 \\
& $(0.2292)$ & $(0.1066)$ & $(<0.0001)$ & $(0.0021)$ \\
\hline \multirow{2}{*}{ Japan } & 0.0022 & -0.0029 & 1.2624 & -0.3630 \\
& $(0.3936)$ & $(0.3867)$ & $(<0.0001)$ & $(0.0965)$ \\
\hline \multirow{2}{*}{ UK } & 0.0017 & -0.0046 & 1.0833 & 0.2588 \\
& $(0.2285)$ & $(0.0601)$ & $(<0.0001)$ & $(0.1133)$ \\
\hline \multirow{2}{*}{ US } & 0.0008 & -0.0014 & 0.7918 & 0.3186 \\
& $(0.6017)$ & $(0.5408)$ & $(<0.0001)$ & $(0.0265)$ \\
\hline \multirow{2}{*}{ UAE } & 0.0115 & -0.0137 & -0.0271 & 1.1234 \\
& $(0.0196)$ & $(0.0203)$ & $(0.9153)$ & $(0.0002)$ \\
\hline
\end{tabular}

Notes:

1. The parameters are estimated by case-resampling bootstrap method. The median values are presented.

2. The number of bootstrap replications is 10000 .

3. The p-values that are based on the casewise bootstrap approach are presented in the parentheses. 
Table 4. Results based on case-wise resampling bootstrap method with beta based on the world real estate index

\begin{tabular}{|c|c|c|c|c|}
\hline \hline Country & Intercept $\left(\alpha_{0}\right)$ & Change in Intercept $\left(\alpha_{1}\right)$ & Slope $\left(\beta_{0}\right)$ & Change in Slope $\left(\beta_{1}\right)$ \\
\hline \multirow{2}{*}{ Australia } & 0.0005 & -0.0019 & 0.7652 & 0.2929 \\
& $(0.6838)$ & $(0.3921)$ & $(<0.0001)$ & $(0.0210)$ \\
\hline \multirow{2}{*}{ Japan } & 0.0001 & -0.0003 & 1.2838 & -0.3841 \\
& $(0.8356)$ & $(0.9193)$ & $(<0.0001)$ & $(0.0179)$ \\
\hline UK & 0.0006 & -0.0024 & 0.9705 & 0.1515 \\
& $(0.6434)$ & $(0.2809)$ & $(<0.0001)$ & $(0.1529)$ \\
\hline US & -0.0001 & 0.0012 & 1.0051 & -0.0402 \\
& $(0.4549)$ & $(0.5037)$ & $(<0.0001)$ & $(0.6919)$ \\
\hline UAE & 0.0121 & -0.0139 & -0.2318 & 1.0230 \\
& $(0.0156)$ & $(0.0243)$ & $(0.3579)$ & $(0.0005)$ \\
\hline
\end{tabular}

Notes:

1. The parameters are estimated by case-resampling bootstrap method. The Median values are presented. The number of bootstrap replications is 10000 .

2. The p-values that are based on the casewise bootstrap approach are presented in the parentheses. 